慶應義塾大学学術情報リポジトリ

Keio Associated Repository of Academic resouces

\begin{tabular}{|c|c|}
\hline Title & $\begin{array}{l}\text { Immunochemical characterization of developmental changes in rat hepatic hydroxysteroid } \\
\text { sulfotransferase }\end{array}$ \\
\hline \multicolumn{2}{|l|}{ Sub Title } \\
\hline Author & $\begin{array}{l}\text { 本間, 浩(Honma, Hiroshi) } \\
\text { 中込，泉(Nakagome, Izumi) } \\
\text { 鎌倉，稔(Kamakura，Minoru) } \\
\text { 松井，道夫(Matsui, Michio) }\end{array}$ \\
\hline Publisher & 共立薬科大学 \\
\hline Publication year & 1992 \\
\hline Jtitle & $\begin{array}{l}\text { 共立薬科大学研究年報 (The annual report of the Kyoritsu College of } \\
\text { Pharmacy). No.37 (1992. ) ,p.73- } 73\end{array}$ \\
\hline \multicolumn{2}{|l|}{ JaLC DOI } \\
\hline \multicolumn{2}{|l|}{ Abstract } \\
\hline Notes & 抄録 \\
\hline Genre & Technical Report \\
\hline URL & $\begin{array}{l}\text { https://koara.lib.keio.ac.jp/xoonips/modules/xoonips/detail.php?koara_id=AN00062898-0000003 } \\
\text { 7-0073 }\end{array}$ \\
\hline
\end{tabular}

慶應義塾大学学術情報リポジトリ(KOARA)に掲載されているコンテンツの著作権は、それぞれの著作者、学会または出版社/発行者に帰属し、その権利は著作権法によって 保護されています。引用にあたっては、著作権法を遵守してご利用ください。

The copyrights of content available on the KeiO Associated Repository of Academic resources (KOARA) belong to the respective authors, academic societies, or publishers/issuers, and these rights are protected by the Japanese Copyright Act. When quoting the content, please follow the Japanese copyright act. 


\title{
Immunochemical Characterization of Developmental Changes in Rat Hepatic Hydroxysteroid Sulfotransferase*
}

\author{
Hiroshi Homma, Izumi Nakagome, Minoru Kamakura and Michio Matsui \\ 本間 浩, 中込 泉, 鎌倉 稔, 松井道夫
}

A major isoenzyme of hepatic androsterone-sulfating sulfotransferase (AD-ST) was purified from adult female rats. The activity was purified 122 -fold over that found in the cytosol and showed a single protein band with a subunit molecular mass of $30 \mathrm{kDa}$ after SDS-polyacrylamide gel electrophoresis. The purified enzyme exhibited four isoelectric variants of subunits on denaturing isoelectrofocusing gels ( $\mathrm{pIs}=5.8,6.1,6.7$ and 7.2).

Rabbit antiserum raised against the enzyme specifically detected AD-ST polypeptide in rat liver cytosol. Immunoblot analysis of liver cytosol from female and male rats at various ages showed good correlation between the levels of AD-ST activity and AD-ST polypeptide. Significant levels of AD-ST activity and polypeptide were detected in senescent male rats, though normal adult male rats have very low levels of AD-ST activity and protein. The relative content of the isoelectric variants of AD-ST were different in liver cytosol of weanling and adult females, indicating that age- and gender-related alterations of hepatic $\mathrm{AD}-\mathrm{ST}$ activity are primarily determined by the levels of $\mathrm{AD}-\mathrm{ST}$ polypeptide and the relative amounts of the four isoelectric variants of the enzyme.

* 本報告は Biochim. Biophys. Acta., 1121, 69-74（1992）に発表. 